\title{
In Vivo Delivery Systems for Therapeutic Genome Editing
}

\author{
Luyao Wang ${ }^{1,+}{ }^{+}$Fangfei Li ${ }^{1,+}$, Lei Dang ${ }^{1,+}$, Chao Liang ${ }^{1}$, Chao Wang ${ }^{1}$, Bing $\mathrm{He}^{1}{ }^{1}$, Jin Liu ${ }^{1}$, \\ Defang $\mathrm{Li}^{1}{ }^{1}$, Xiaohao $\mathrm{Wu}^{1}{ }^{1}$, Xuegong $\mathrm{Xu}^{2, *}$, Aiping $\mathrm{Lu}^{1, *}$ and Ge Zhang ${ }^{1, *}$ \\ 1 Institute for Advancing Translational Medicine in Bone \& Joint Diseases, School of Chinese Medicine, \\ Hong Kong Baptist University, Hong Kong 00852, China; luyaoben@126.com (L.W.); \\ fayebalaba@live.com (F.L.); danglei_hkbu@163.com (L.D.); liangchao512@163.com (C.L.); \\ wangchao@hkbu.edu.hk (C.W.); hebinghb@gmail.com (B.H.); liujin_hkbu@163.com (J.L.); \\ lidefang@163.com (D.L.); wxho0606@163.com (X.W.) \\ 2 Central Laboratory, Zheng Zhou Hospital of Traditional Chinese Medicine, Zhengzhou 450000, China \\ * Correspondence: xuxg1115@126.com (X.X.); aipinglu@hkbu.edu.hk (A.L.); zhangge@hkbu.edu.hk (G.Z.); \\ Tel.: +86-371-6744-4807 (X.X.); +852-3411-2456 (A.L.); +852-3411-2958 (G.Z.) \\ + These authors contributed equally to this work.
}

Academic Editor: Izuho Hatada

Received: 15 February 2016; Accepted: 14 April 2016; Published: 27 April 2016

\begin{abstract}
Therapeutic genome editing technology has been widely used as a powerful tool for directly correcting genetic mutations in target pathological tissues and cells to cure of diseases. The modification of specific genomic sequences can be achieved by utilizing programmable nucleases, such as Meganucleases, zinc finger nucleases (ZFNs), transcription activator-like effector nucleases (TALENs), and the clustered regularly-interspaced short palindromic repeat-associated nuclease Cas 9 (CRISPR/Cas9). However, given the properties, such as large size, negative charge, low membrane penetrating ability, as well as weak tolerance for serum, and low endosomal escape, of these nucleases genome editing cannot be successfully applied unless in vivo delivery of related programmable nucleases into target organisms or cells is achieved. Here, we look back at delivery strategies having been used in the in vivo delivery of three main genome editing nucleases, followed by methodologies currently undergoing testing in clinical trials, and potential delivery strategies provided by analyzing characteristics of nucleases and commonly used vectors.
\end{abstract}

Keywords: in vivo delivery systems; vectors; genome editing; programmable nucleases

\section{Introduction}

Therapeutic genome editing is mediated by sequence-specific targeting nucleases, also known as programmable nucleases. To date there are three major classes of programmable nucleases: zinc finger nucleases (ZFNs), transcription activator-like effector nucleases (TALENs), and the clustered regularly-interspaced short palindromic repeat-associated nuclease Cas9 (CRISPR/Cas9) [1]. They opened up the possibility of achieving, directly, correcting genetic mutations in target pathological tissues and cells to cure diseases (Figure 1). Compared to the other two powerful genetic therapeutic technologies, gene therapy and RNA interference, genome editing technologies enable more precise gene modulation by inducing DNA DSBs at specific genomic site via designing targeted nucleases with site-specific DNA binding domains [1,2]. ZFNs and TALENs, sharing the same FokI-derived nuclease domain, employ different DNA binding arrays: zinc finger arrays, and TAL effector repeats $[3,4]$. CRISPR/Cas9 employs sgRNA to induce site-specific genome editing in target cells with high frequency [5]. However, inefficient modification of target loci often results from inefficient delivery, making cells lack robust delivery platforms. Clinical applications of these programmable nuclease 
complexes are hampered by their inability to reach the intended target tissue, cross the cell membrane, and exert their therapeutic activities in vivo.

Both physical methods and delivery vectors are employed in the delivery of nuclease-based genome editing system (Figure 2). In physical methods, such as microinjection, electroporation, ballistic delivery, and laser, physical energy is used for cell entry [6]. Nevertheless, physical methods are more suitable for in vitro delivery. Vectors, like viral vectors and non-viral vectors, can encapsulate the plasmid or mRNA of these programmable nucleases or nuclease proteins, and carry them into target tissues or cells without degradation. Development of safe and efficient delivery vectors becomes more and more significant. To date, vectors used for gene-based systemic delivery in clinical trials include viral vectors [7] such as lentivirus vectors (LVs), adenovirus vectors (AdVs), adeno-associated virus vectors (AAVs) and herpes simplex-1 virus vectors (HSV-1s), and non-viral vectors [8] such as lipid nanoparticles (LNPs), liposome, polymers, and conjugates, as well as some novel ones such as cell-derived membrane vesicles (CMVs) [9]. Being exploited as a "Trojan Horse" for genome therapeutic technologies, viral vectors whose parental wild-type viruses are rearranged to hinder replication or generation of infectious virions. On the contrary, their ability of delivery nucleic acids for reaching and penetrating specific target cells and expressing genetic information in these cells is maintained [10]. Ideal virus-based vectors for therapeutic genome editing can avoid the expression of viral genes and consequently avert the toxicity. However, even being rearranged, the perishing adverse effects of viral vectors still exist. A clinical trial of applying the gene for ornithine transcarbamylase (OTC), delivered by the second-generation of E1 and E4 deleted AdVs, on the liver of the patient (Gelsinger) who suffered from a partial insufficiency of OTC caused the patient's death in 1999. There were also some similar accidents, such as the retroviral vector inducing a lymphoproliferative disorder (2002-2003) [7]. Hence, the toxicity of viral vectors is a major issue of concern when applying viral vectors in genome editing therapy.

Compared to viral vectors, non-viral vectors are a type of burgeoning vectors. They have the potential to address limitations of viral vectors such as immunogenicity [11], carcinogenesis [12], and limited encapsulating capacity [7]. Nevertheless, only a few non-viral vectors mediated gene therapy strategies have so far been applied in clinical trial owing to the low in vivo delivery efficiency of non-viral vectors relative to viral vectors. Additionally, several recently-reported non-viral vectors under clinical evaluation in 2014 [8], only one non-viral vector of a total 2210 vectors was reported in the statistics on the topic of "Vectors Used in Gene Therapy Clinical Trials", while 66.4\% of vectors applied in gene therapy clinical trials were viral vectors [13]. Now this drawback is overcome by modifying raw materials of non-viral vectors and improving engineering recipes. For example, in 2015, Chunyang Sun's group reported their novel study on an established $\mathrm{pH}_{\mathrm{e}}$ (dysregulated $\mathrm{pH}$ scale in tumor) sensitive micelleplex siRNA delivery system whose corresponding nanoparticles (Dm-NP) might undergo several modifications, and the results showed that the novel delivery system they produced can specifically target cancer cell [14]. Furthermore, many other types of vectors made from neoteric materials, such as the endogenous carriers, cell-derived membrane vesicles (CMVs), are also extensively studied [9].

In this review, we summarized current strategies of in vivo delivery of three main genome editing nucleases, followed by methodologies undergoing evaluation in clinical trials, as well as suggestions on potential delivery strategies by analyzing characteristics of nucleases and commonly-used vectors (Table 1). Considering the clinical translation, promising vectors under clinical investigations are highlighted. 


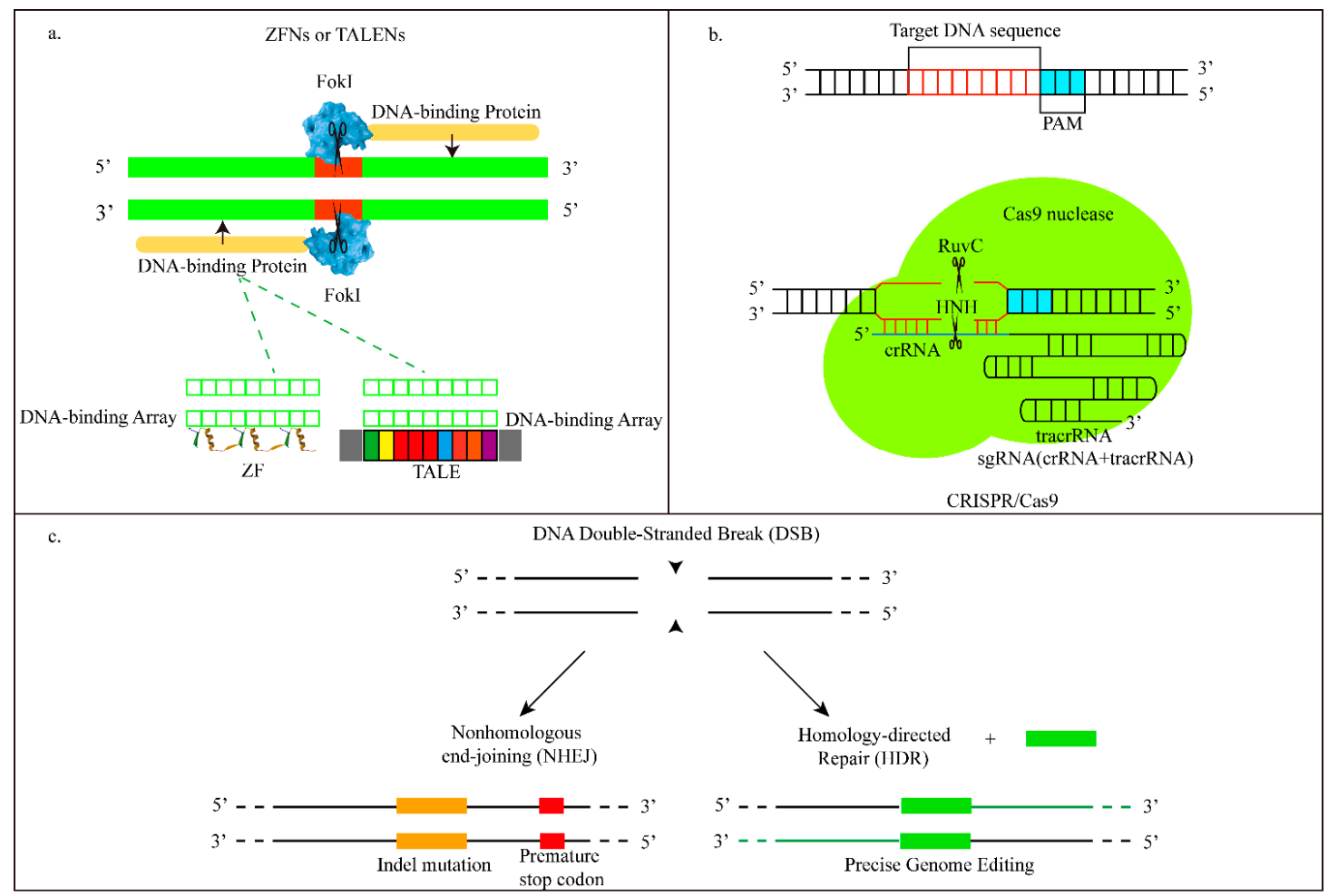

Figure 1. Endogenous DNA repair and three genome editing tools. (a) Zinc finger (ZF) and transcription activator-like effector (TALEs) proteins are DNA-binding domains which can be modularly combined to bind targeted sequences. ZF and TALE domains can separately recognize three and one bp of DNA. These site-specific nucleases are the fusion of DNA-binding domains and FokI endonucleases; (b) Cas9 nucleases in the clustered regularly-interspaced short palindromic repeat-associated nuclease Cas9 (CRISPR/Cas9) system target specific DNA sequences with the guide aid of sgRNA, then directly achieve base-pairing with target sequences. The binding of the Proto-spacer adjacent motifs (PAM, blue) downstream of target sites aids to directing Cas9-mediated double-stranded break (DSB); and (c) DNA DSBs can be typically repaired via non-homologous end-joining (NHEJ) or homology-directed repair (HDR), from reference [15].

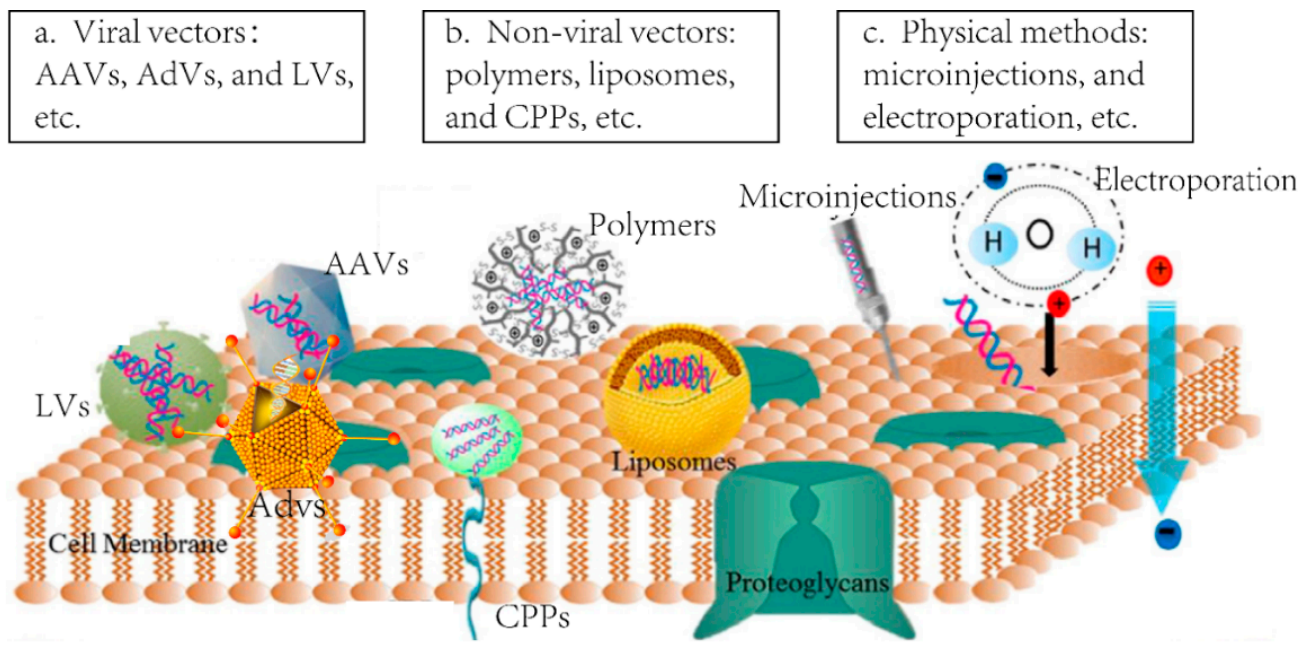

Figure 2. Current techniques used for gene delivery. (a) Viral vectors containing adeno-associated virus vectors (AAVs), adenovirus vectors $(\mathrm{AdVs})$, and lentivirus vectors (LVs), etc.; (b) non-viral vectors containing polymers (e.g., polyethylenimine-PEI, poly(L-lysine)—PLL), liposomes (e.g., 1,2-dioleoyl-3-trimethylammonium-propane-DOTAP, cholesterol), and cell-penetrating peptides (CPPs), etc.; and (c) physical methods containing microinjections, and electroporation, etc., from reference [16]. 


\section{In Vivo Delivery Systems for Zinc Finger Nucleases (ZFNs) and Their Expression Cassette}

Zinc finger nucleases (ZFNs) are the first sequence-specific designer nucleases for gene editing. ZFNs consist of a DNA recognition domain (Zinc finger proteins, ZFPs) which is composed of 3-6 $\mathrm{Cys}_{2}-\mathrm{His}_{2}$ zinc fingers and a non-specific DNA cleavage domain (derived from FokI endonucleases) via the C-terminal of the cleavage domain $[17,18]$. Each zinc finger domain of ZFPs can recognize 3- to 4-bp DNA arrays via a single $\alpha$-helix, and several tandem zinc finger domains can typically recognize and bind to DNA sequences with the length of multiple of three, normally 9- to 18-bp with high specificity [19]. Then DNA cleavage domains in ZFNs can cut the DNA sequence recognized by the ZFPs [19]. By this mechanism, ZFNs-based genome editing technologies are used to alter genomic sequences to correct a mutation or create a mutation.

Actually, before developing ZFNs, homing endonucleases (HEs), the natural meganucleases, have been utilized for genome editing for more than 15 years [20-27]. Compared to HEs, ZFNs-based genome editing technologies are more effective. A representative example is a mutation created by ZFPs-based genome editing in C-C chemokine receptor type 5 (CCR5) making cells resistant to HIV infection [28]. Nevertheless, unwanted off-target effects cannot be avoided because the wild-type FokI enzyme can still cleave the non-target DNA even when only one monomer binds to this DNA sequence [29]. Efforts to improve the specificity of ZFNs include the development of heterodimer cleavage domains, optimization of the spacer requirements between two target DNA sections via linker design, enhancement of cleavage activity through directed evolution of the FokI nuclease, as well as investigation of a proper and efficient in vivo delivery system. Commonly used in vivo delivery vectors for ZFNs system are presented as follows:

\subsection{Viral Delivery}

The thought of using viruses as vectors to deliver a package of genetic information to achieve gene therapy was firstly successfully demonstrated in 1990, when the purified, healthy T-lymphoid cells of a patient suffered from both adenosine deaminase deficiency (ADA) and immunodeficiency (SCID) were redelivered in the body via a retroviral vector. This therapy repaired the immune system of the patient. [30]. Two main parts of the virus life cycle are infection and replication. In the infection step, virus enter into target cells after recognition, then release the viral genome for replication. In the replication step, progeny virions are released outside cells after synthesizing the viral genome copies in cells. Then, new infection steps in nearby cells or circulation begin [10]. Based on this mechanism, viruses are used as vectors to encode and deliver genome editing programmable nucleases to target tissues or cells, and achieve genome editing therapy.

\subsubsection{Adenoviral Vectors (AdVs)}

Adenoviruses (Ad), belonging to the family of Adenoviridae, were firstly discovered in 1953 and isolated from cultures of human adenoid tissues. The first-generation adenoviral vectors (AdVs) are obtained by substituting the gene E1 $(3.15 \mathrm{~kb})$, or the E1 and E3 $(3.1 \mathrm{~kb})$, followed by the second-generation AdVs, which lack more than two early genes, including E2 and E4. Compared to the first generation, the second-generation AdVs provide an extended genome packaging capacity. However, it is limited by the inflammatory response of the host and the inability of replicating in vivo including a cytotoxic T-cell response [31,32]. Considering this situation, the production of safer and more efficient AdVs, targeting site-specific sequences of the disease, has therefore become a trend [33]. For systemic delivery of ZFNs, here is a good example which is against HIV infection and has entered clinical trials: the expression unit coding the right and left ZFNs is inserted into a serotype $5 \mathrm{AdV}$ pseudotyped with serotype 35 fiber (AdV5/35). The AdV/ZFNs system is designed to repair the autologous $\mathrm{CD}^{+}$helper T cells from HIV infected patients [34,35].

A shortcoming of AdVs: as the receptor of Ad on cell, the Coxsackie-adenovirus receptor (CAR) level determines the delivery efficiency of AdVs. For instance, the expression level of CAR in cancer cells is mutable probably negative correlation to the malignancy level of the tumor, which means the 
CAR is rare in cancer cells. Therefore, investigating the targeted AdVs specifically for cancer cells is playing an emerging role in anti-tumor research via genome editing technology.

\subsubsection{Lentiviral Vectors (LVs)}

Lentiviral vectors, members of the retrovirus family which can spontaneously penetrate the intact nuclear membrane, have now been commonly used for in vivo delivery in genome editing therapy. As the delivery vector of ZFNs technology, lentiviral vectors which can accommodate sequences up to around 10 kilobases $(\mathrm{kb})$ theoretically allow for site-specific genome modification or addition in predefined genomic sites. However, they have been avoided because of multiple tragedies involving patient death in earlier clinical trials [36,37]. Therefore, advanced types, such as Integrase-Defective Lentiviral Vectors (IDLVs) have been heavily explored in recent years.

For instance, Angelo Lombarbo's research group exploited one ZFNs-based genome editing system in human stem cells using IDLVs as delivery vectors [38]. The results showed up to $50 \%$ of genome addition in one dish of human cell lines, and $5 \%$ of genome addition in human embryonic stem cell lines. However, the efficiency of IDLVs may vary according to target tissues. For example, the transduction efficiency of hepatocytes in mice with IDLVs is less than integrating LVs, while IDLVs can achieve highly-effective gene transfer and expression in mice muscle in vivo $[37,39]$.

\subsubsection{Adeno-Associated Viruses Vectors (AAVs)}

Adeno-associated viruses vectors (AAVs), the commonly used delivery vector in genome editing technologies for its potential site-specific integration ability and low immunogenic characteristics, are icosahedral non-enveloped viruses in the Dependovirus genus of Parvoviridae family. The major limitation of AAV vectors system is their relatively small genome size (around $4.7 \mathrm{~kb}$ ), which restricts the genome engineering nuclease complexes they can carry up. However, with careful design, sequences for expressing ZFNs (each sequence is around $1 \mathrm{~kb}$ ) and an optional donor DNA template can be encapsulated well by AAV vectors [10].

The representative type of AAV vectors system is the modified one: recombinant vectors based on adeno-associated viruses (rAAV) which have been heavily explored in recent years [40]. One ZFNs-mediated gene editing drug being designed to be carried via rAAV vector to stimulate gene targeting was reported in 2013 [41]. In this research, rAAV/ZFN particles with DNA restoration substrate of 750 nucleotides were generated. The delivery efficiencies of rAAV to both human HEK-293 cell lines "293/GFP" and primary mouse fibroblasts were estimated in vitro, as well as in mouse and dog models in vivo. Results generally showed that increased AAV-ZFN2/1/donor vectors leaded to better targeting effect. Additionally, multiple other investigations on AAV/ZFNs-mediated genome editing have been obtained the positive results in animal model in vivo experiments [42-45]. For instance, there is one study on the in vivo modification of a humanized mouse model of hemophilia B: in this study, the introduction of AAV on ZFNs achieved up to $45 \%$ site-specific cleavage of the hepatocytes [46].

\subsection{Non-Viral Vectors}

Non-viral vectors in non-viral methodologies for genome editing can be classified into several sub-types according to their raw materials, size, or producing recipes, and so forth. For instance, they can be sorted into lipid-based vectors, and polymer-based vectors, and the like, when raw materials are lipids, polymer, etc. Lipid-based vectors can then be classified as lipid nanoparticles (LNPs) and liposomes, and so on, according to various producing recipes and sizes. Liposomes, polymersomes, LNPs, lipoplexes, polyplexes, dendrimers, and cell-penetrating peptides (CPPs) are commonly used to deliver genes.

Compared to immunogenic viral vectors, whose capacities are relatively small, non-viral vector-mediated strategies possess advantages of low toxicity, high gene transfection efficiency, large loading capacity and easy producing procedures. However, the low transfection efficiency plus the poor transgene expression impede the clinical application of non-viral vector-based delivery 
strategies. Therefore, to improve the transfection efficiency and transgene expression, as well as enhance the targeting efficacy and safety of delivery approaches, many studies have been done. For instance, existing liposomes, polymers and peptides-based vectors are all improved. Cationic liposomes are found to be effective for its high transfection efficiency and biocompatibility since being firstly investigated and published by Felgner's group in the late 1980s [16,47]. However, there is rarely a report or clinical record on non-viral vector-mediated in vivo delivery of meganucleases for genome editing [24,25].

Given the positive charge of ZFNs particles encapsulated by cationic lipids and cationic polymers is attracted to the negative charge of cell membranes, using cationic lipid nanoparticles or cationic polymers as vectors will induce the cellular uptake of genome editing nucleases, such as ZFNs [48]. However, there is no report on the in vivo delivery of ZFNs by cationic lipid nanoparticles, and while some in vitro research is published [49,50], neither are cationic polymers.

\subsection{Direct Delivery of ZFN Proteins}

Passing through troubles which exist both in the cell membrane penetrating process of proteins caused by its low level of lipophilicity and in vivo, such as $\mathrm{pH}$ sensitivity and degradation by endogenous proteases, ZFN proteins can surprisingly penetrate cell membranes due to the positive charge of $\mathrm{Cys}_{2}-\mathrm{His}_{2}$ zinc finger domains [51]. The results showed that the direct delivery of ZFN proteins can disrupt the CCR5 gene in both HEK-293, HDF cells, and human CD4 ${ }^{+} \mathrm{T}$ cells. Even though its motion in vivo is unclear, the in vivo delivery efficiency can still be demonstrated. Moreover, compared to ZFN plasmid delivery, the off-target mutagenesis of this methodology are reduced (ClinicalTrials. Gov Identifier: NCT01044654, NCT01252641 and NCT00842634) [52]. Increasing the stability of ZFN proteins is vital to achieve the direct delivery of ZFN proteins, because ZFN proteins will be degraded completely in four hours. One of possible strategies to keep ZFN stable is to modify the lysine residue needed in the degradation $[53,54]$.

\subsection{Summary and Prospect}

Much research has shown that ZFNs can mediate genome editing efficiently by making site-specific DSBs then inducing homology-directed repair (HDR) in target cells and the appropriate alternative and development of the in vivo delivery system is critical to clean barriers hampered on its clinical translation way. So far, AAVs-based ZFNs genome editing therapy in vivo is increasingly applied in clinical trials. AAVs/ZFNs-mediated in vivo gene correction in the mouse model of hemophilia is a good example [55]. AAVs, having been investigated and developed maturely as vectors via constant improvement, are commonly used in carrying ZFNs rather than TALENs or CRISPR/Cas9 for their relative small cargo size. To date, there is no AAVs/ZFNs-based genome editing therapeutic methodology being applied in clinical trials. By contrast, as the presentation above, the strategy of directly delivering ZFN proteins into target cells to achieve genome editing has been in clinical trials (Table 1). In addition, non-viral vectors, possessing advantages of low toxicity, high gene transfection efficiency, large loading capacity, and easily-produced procedures, deserve to be investigated. Filling the gap in ZFNs-based genome editing technology on non-viral vectors mediated delivery system, investigating novel and efficient non-viral vectors mediated delivery strategy is needed.

\section{In Vivo Delivery Systems for Transcription Activator-Like Effector Nucleases (TALENs) and Their Expression Cassette}

Transcription Activator-Like Effector Nucleases (TALENs), similar to ZFNs, also consist of two domains, a DNA-binding domain and a C-terminal FokI endonuclease cleavage domain. The DNA-binding domain is composed of multiple units of 33 35 amino acid repeat arrays arranged in tandem, and it is contained in TALEs, which are natural proteins of the plant pathogenic bacteria Xanthomonas sp. [18]. In contrast to ZFPs, TALENs possess advanced advantages such as lower cytotoxicity [56], greater design flexibility leading to higher targeting range [57], and easier engineering. However, there is no single site-specific TALEs with long arrays due to the lack of the linkage between 
repeats. These TALE repeats are nearly identical in sequence. Fusing TALEs to the FokI endonuclease, TALENs bind and cleave the target DNA in pairs [58].

In summary, ZFNs and TALENs both consist of an engineered DNA-binding domain and a FokI nuclease domain. DNA-binding domains, engineered ZF and TALE repeats, can bind to gene sequences after being arranged in tandem. Then ZFNs and TALENs can achieve customized genome editing in target cells. To date, several in vivo vectors are available for delivery of TALENs by carrying their expression cassettes (more than $5 \mathrm{~kb}$ ) which usually consist of the RNA polymerase II (Pol II) promoter, the TALE encoding sequence, the FokI nuclease domain, and the polyadenylation signal [32]. AAV, the promising delivery vehicles for transgenes of ZFNs, would be not able to afford accommodating TALENs for its relatively small cargo size of $\sim 4.7 \mathrm{~kb}$ [59]. Nevertheless, the other viral vectors with larger capacity can be investigated (Table 1 ).

\subsection{Viral Vectors}

\subsubsection{Lentiviral Vectors (LVs)}

To deliver genome editing nucleases effectively, lentivirus have been developed for several generations from the early generation which contains the gene of cis-acting elements, such as the long terminal repeats to the second generation in which multiple non-essential accessory genes are deleted and self-inactivating vectors are established in order to avoid the unwanted generation of replication-competent lentiviral vectors (LVs) and the activation of nearby genes due to genomic integration and then the lentiviral trans-activator of transcription-independent vectors were generated in the third generation. Moreover, the central PolyPurine Tract (cPPT) for increasing vector transduction efficiency and the Woodchuck hepatitis virus post-transcriptional regulatory element (WPRE) for enhancing transgene expression levels were inserted into the recombinant LV genome [32]. However, it seems that sufficient delivery and expression of TALENS in mammalian cells via commonly-used versions of LV vector systems is not feasible, because of their potential mutagenicity caused by the deletion of complete repeats that occurred during vector production ranging from 5 to 15 repeats per TALEN [60].

\subsubsection{Adenoviral Vectors (AdVs)}

Compare to lentiviral vectors, AdVs-mediated TALEN genome editing therapy can result in analogously high level site-specific DSBs both in transformed cells and non-transformed cells [61]. As the statement above, the first and second generation AdVs are not optimal vectors for therapeutic approaches due to their immune side effect in vivo, even though Holkers and colleagues have demonstrated that these AdVs can carry the TALEN expression cassette into human cells [60]. The most advanced version of AdVs are represented by high-capacity AdVs (HCAdVs) without all viral coding sequences, but only the inverted terminal repeats (ITR) and the packing signal at the $5^{\prime}$ end of the genome being maintained. They can be typically distinguished from the common AdVs by the reduced induction of innate and adaptive immune responses, as well as providing a total packaging capacity of up to $36 \mathrm{~kb}$ which offers great potential for delivery of large TALEN expression cassettes [32].

\subsubsection{Baculoviral Vectors (BVs)}

Baculoviral vectors (BVs), derived from the insect Autographa californica multiple nuclear polyhedrosis virus, can accommodate 100-kb of DNA insert leading to a usage for delivery of TALEN plasmid. One research, developing a BVs-TALENs coupled with BVs-Cre/loxP genome editing tool, offers a novel strategy for TALEN-based genome editing with low genome toxicity in engineering human pluripotent stem cells. The results demonstrate that BVs-TALENs are effective in mediating genetic modification. However, TALEN-repeated sequences in a BV do not obviously affect overall TALENs activity. The present application of BVs on carrying genome editing nucleases is still limited to ex vivo status [57]. 


\subsection{Non-Viral Vectors}

\subsubsection{Cationic Polymer-Based Vectors}

As described above, cargo size is a problem for in vivo delivering of TALENs. The plasmids encoding TALENs, being easier to be encapsulated, are commonly delivered into tissues or cells in vivo via therapeutically-efficacious cationic polymers. One vector made of cationic polymers (TurboFect ${ }^{\circledR}$ ) is utilized to carry TALEN plasmids, targeting human papillomavirus (HPV), directly to the cervix of transgenic mice displaying HPV infection and cervical cancer. After this therapy, the tumor size is reduced, while neither off-target mutations nor signs of inflammatory response are detected [62]. Comparatively speaking, cationic lipids are rarely applied in delivering TALENs for genome editing.

\subsubsection{Conjugates}

Refer to the methodology on direct delivery of ZFN proteins, direct delivery of TALEN proteins instead of transgenes has also been investigated. However, unlike the naturally cell-penetrating ZFNs, TALEN proteins are found to be incapable of penetrating cellular membranes when administered alone. Thus, cell-penetrating peptides (CPPs) are always utilized to promote the cell penetration of TALEN protein. Functional TAT-TALENs (YGRKKRRQRRR-TALENs), the conjugation of cell-penetrating TAT peptides and TALENs, can penetrate targeted cells and damage the genome encoding endogenous human chemokine receptor 5 (CCR5) to prevent HIV-1 from entering into cells [63]. On the contrary, this methodology is not suitable for ZFN proteins because a large amount of purification of TAT-ZFNs is so hard to achieve that the quantity cannot satisfy the analysis-required amount in cell lines. Similarly, the cell-penetrating poly-Arg9 peptides-TALEN proteins fusion enables TALEN-based genome editing of human CCR5 genes in HeLa cell lines and BMPR1A genes in HEK-293 cells, respectively [64].

\subsection{Summary and Prospects}

Due to the large size of TALENs and repetitive characteristics, it is difficult to achieve in vivo delivery of TALENs into targeted tissues or cells. Especially when lentiviral vectors are used for packaging, unwanted recombination events will be resulted in. Considering these above, proper delivery vectors for TALENs include high-capacity AdVs (HCAdVs), cationic polymers, and cell penetrating peptides (CPPs)-TAT, but all have not been into clinical trials yet.

\section{In Vivo Delivery Systems for CRISPR/Cas9 and Their Expression Cassette}

The CRISPR/Cas (Clustered regularly interspaced short palindromic repeat- associated nuclease Cas) system consists of two components: guide RNA (gRNA) and nucleases (Cas). This system is the immune system of some bacteria used for defending against foreign nucleic acids [65-68]. Various CRISPR/Cas system types achieve nucleic acid recognition in various molecular mechanisms. The most commonly used type is CRISPR/Cas9 including a conjugation of the tracrRNA (trans-activating crRNA) - crRNA (CRISPR RNA) to a single guide RNA and Cas9. Cas9 protein, derived from Streptococcus pyogenes or Staphylococcus aureus, is significantly multifunctional to defend against viral invasion [69]. CRISPR/Cas9 achieves site-specific DSBs after being led to target loci by crRNA associated with tracrRNA. Unlike ZFNs and TALENs, which both need to be particularly made according to different target loci owing to the mechanism that they are guided by protein domains, the CRISPR/Cas9 system can bind to any interested target sequences simply via altering gRNA and achieve DSBs [70].

However, the large size of the CRISPR/Cas system presents an obstacle for its delivery in vivo. The size of the common-type spCas9 (from the bacterial species Streptococcus pyogenes) is $\sim 4.2 \mathrm{~kb}$, which states a challenge to package it while $\mathrm{AAV}$, whose cargo size is $\sim 4.5 \mathrm{~kb}$, is utilized as a vector [71]. Even though the cargo size of non-viral vectors like cationic liposome or PEI can be made up to much larger than $4.5 \mathrm{~kb}$, the endothelial gap size limitation of blood vessels and so forth also exist to hamper the delivery of the CRISPR/Cas system to targeted tissues for genome editing therapy in vivo. The limited cargo size of vectors leaves little space for engineered expression or control domains. To solve this 
kind of problem, a slightly smaller type saCas9 (from species of Staphylococcus aureus, $\sim 3.2 \mathrm{~kb}$ ), which is still efficient and broadly-targeting, has recently been investigated [71]. On these bases, delivery vectors are developed as follows:

\subsection{Viral Vectors}

Until now, AAV has been well-developed and utilized in delivering the CRISPR/Cas system into targeted issues and cells such as brain cells via stereotactic injection in adult mouse brains [72], as well as skeletal and cardiac muscle cells by tibialis anterior muscle injection in $m d x$ mouse muscle, and so on [58]. In a mammalian brain study, SpCas9 and gRNAs are delivered by separate AAVs respectively, with shortened neuron-specific promoters in vivo in order to target and edit both single (Mecp2) and multiple (Dnmt1, Dnmt3a, and Dnmt3b) genes in the adult mouse brain [72]. On the basis of the significant finding on the smaller Cas9 enzyme-saCas9 [71], three newer studies focus on in vivo CRISPR/Cas9-based genome editing via delivering a saCas9 plasmid or Cas9 mRNA into the $m d x$ mouse model by AAV8 or AAV9 to cure Duchenne Muscular Dystrophy (DMD) [59,73,74]. For instance, Mohammadsharif Tabebordbar and collaborators developed a direct genome editing approach based on the CRISPR/saCas9-AAV system and applied it to the $m d x$ mouse model to introduce exon deletion and dystrophin expression restoration, and test the efficiency of different Cas9 serotypes to obtain the most efficient one. Results showed that the AAV-CRISPR system partly restored the muscle functional deficiency in $m d x$ mouse muscle [73]. Moreover, many other investigators are also devoted to develop the AAVs delivery system for targeting CRISPR/Cas to different interesting tissues or cells in vivo, such as the central nervous system, cancer cells, and so forth [71,75-79].

However, the small cargo size continues to hamper AAVs as delivery vectors of the CRISPR/Cas system. To accommodate larger payloads, other viral vectors with larger capacities, such as adenoviral and lentiviral vectors, have also been investigated by various researchers for the CRISPR/Cas9 system delivery [80].

\subsection{Non-Viral Vectors}

\subsubsection{Cationic Lipid-Based Vectors}

The anionic nature of both Cas9 protein itself, and the plasmid or mRNA encoding it, as well as gRNA, allows the integration of Cas9-gRNA complexes into the cationic liposome, which means the CRISPR/Cas9 genome editing system could be delivered via cationic liposomes. One successful case is on the Cas9 protein/sgRNA system which is encapsulated and carried to hair cells by cationic liposomes to achieve genome editing therapy in the mouse inner ear in vivo [81]. This approach results in up to $80 \%$ gene modification in cultured hair cells. However, it is injected directly into the inner ear of mice, but not intravenous injection which is more efficient and closer to the clinical injection approach, but more challenged. There is still a long way to go to achieve the in vivo delivery of the CRISPR/Cas system.

Up to now, to solve the encapsulating and in vivo delivery problem on the large-size CRISPR/Cas9 system, the methodology of separately encapsulating Cas9 plasmids (or Cas9 mRNA) and gRNA in two vectors, which calls for smaller cargo size, is involved into in vivo genome editing technology in addition to senior strategies, such as carrying the saCas9/sgRNA system [74].

\subsubsection{Cationic Polymer-Based Vectors}

Similar to the mechanism of cationic liposomes, the cationic nature of cationic polymer nanoparticles also provides themselves the feasibility for delivery of the CRISPR/Cas9 system. Polyethyleneimine (PEI), the most common cationic polymer, consists of a secondary amine which can help to prevent DNA and endosomal escape through the proposed proton sponge effect. In addition, the structural properties, degree of branched or linearity, and molecular weight also play a vital role in deciding the transfection efficiency and toxicity of PEI [82]. Here is one example in which PEI-CRISPR/Cas9-mediated somatic genome disruption technology is established to achieve the in vivo targeting of tumor suppressor genes (TSGs) and delete single (Ptch1) and multiple (Trp53, Pten, 
Nf1) genes in the mouse brain. Nevertheless, the low spatial accuracy of transgene expression leading to low viability became its drawback [83]. Furthermore, the branching degree and the molecular weight of PEI are strongly influential to its transfection efficacy and toxicity. In details, PEI with a higher molecular weight, higher branching degree, and bigger cationic charge can form small polyplex with high enzymatic stability but accompany with the unwanted increase in the cytotoxicity. On the contrary, lower molar mass leads to less cytotoxicity, but also less efficiency [84].

To improve the transfection efficiency but decrease the cytotoxicity, many modifications of PEI are developed and some of them have been used in clinical trials. The IL-12-PEG-PEI-cholesterol lipopolymer treating persistent and recrudescent epithelial ovarian, and primary peritoneal cancer, and so on is a realizable example [84,85]. Moreover, another interesting research focuses on carrying the CRISPR/Cas9 system using 7C1 nanoparticles which are synthesized via blending C15 epoxide-terminated lipids with the low molecular weight PEI. This methodology improves the gene mutation efficiency in the pulmonary and the cardiovascular endothelium, as well as reproduces Cre-dependent Cas9 mice [77].

\subsubsection{Conjugation}

Similar to TALENs, not only can encapsulating achieve to carry and deliver CRISPR/Cas9 system in vivo, conjugating is also available. Suresh Ramakrishna and colleagues present cell-penetrating peptides (CPP)-based delivery methodology in which the gRNA is complexed with CPP to form condensed and positively-charged nanoparticles, while the Cas9 protein is fused with CPP by the thioether bond. This induces efficient genome editing with reduced off-target mutations in human cells, like embryonic stem cells, HEK-293T cells, and HeLa cells, and so forth. In addition, this strategy does not need extra transfection reagents, and directly carries gRNA and Cas9 protein to reduce off-target effects [86].

\subsection{Combined Viral and Non-Viral Delivery}

Recently, a novel in vivo delivery approaches for CRISPR/Cas9 was established by Xue and Anderson's laboratory. They combined viral and non-viral vectors, respectively carried mRNA of Cas 9 via lipid-based vectors, and generated AAVs encoding sgRNA with the repair template. They then applied this genome editing approach to a mouse model of human hereditary tyrosinemia to induce the repair of the disease gene. The repair efficiency was more than $6 \%$ in hepatic cell lines. In addition, fumarylacetoacetate hydrolase (Fah)-positive hepatic cell lines were generated [87]. A HDR template was involved into the genome editing system and recombination of segmental HDR-mediated donor templates may happen in gene repair. Hence, the targeted in vivo delivery of a HDR-mediated donor template to specific genomic locus will also be crucial to therapeutic genome editing $[88,89]$.

\subsection{Summary and Prospects}

The CRISPR/Cas9 system can be delivered in vivo in the form of Cas9 proteins/gRNA, plasmids encoding Cas9/gRNA, or mRNA encoding Cas9/gRNA. Plasmids with gRNA is commonly used due to the difficulty of delivering the other two forms: the size of proteins is too large to deliver in vivo followed by the immune response of proteins in body, while the cost of producing mRNA is too high to afford on. On basic of this, presently successful in vivo delivery systems for CRISPR/Cas9 include AAV, cationic liposomes, PEI, and CPP. In addition, hydrodynamic injection is also applied to assist in achieving carrying a large-size CRISPR/Cas9 system into mouse hepatic tissue in vivo $[89,90]$. Physical means such as electroporation and microinjection, facilitating uptake of plasmids into target cells, show the potential. Some electroporation-induced genetic modification in vitro, in vivo, and in utero are successful examples [91]. Moreover, a formulation comprising non-ionic poloxamer CRL 1005 and cationic surfactant benzalkonium chloride has entered into Phase II/III clinical study [92] (NCT01877655, NCT01903928, NCT00285259). 


\section{Conclusions and Future Perspectives}

The presently-existing three programmable nuclease systems all offer pros and cons (Table 2). In conclusion, ZFNs show relatively weaker cleavage of chromosomal DNA, while TALENs possess almost $100 \%$ cleavage efficiency in mammalian cell lines [93]. Nevertheless, the high mutation rates of TALENs caused by mismatched dimer formation cannot be ignored [94]. In addition, unlike ZFNs being effective on both deletion and insertion, it is easier for TALENs to induce deletion than insertion [95]. By contrast, various Cas nucleases can be guided to different target gene sequences easily via just altering the gRNA, and the customized gRNA can be synthesized in one cloning procedure. Each coin has two sides, the convenience of the Cas9/sgRNA system of CRISPR is also the main difficult part of encapsulating and delivery in vivo. These disadvantages, above all, hampered the transition of nuclease-based genome editing technologies from basic studies to clinical trials (Table 3).

To solve this challenge, establishing effective in vivo delivery systems is crucial to the clinical transition of genome editing therapy. Up to now, these nucleases have been mainly delivered in vivo by viral vectors and non-viral vectors. Among them, viral vectors possess superiorities of not causing potential problems of insertional mutagenesis and having high transduction efficiency, as well as long-term fine genome expression. However, limitations still exist, such as immunogenicity, expense, and small cargo size. The well-developed viral vectors, such as AAVs and LVs, which both do well in carrying ZFNs (smaller size) into target cells, are limited in the delivery of TALENs and CRISPR/Cas9. In details, only one TALEN element with one tiny promoter sequence can be encapsulated into AAVs, and it may cause undesirable rearrangements of TALEN's high homologous sequences in cells while using LVs as their delivery vectors [61,96]. For CRISPR/Cas9, only the saCas9/sgRNA system can fit into AAVs. Even though there are some reports on integrating LVs-encapsulated Cas9/sgRNA-based genome editing therapies with nearly $100 \%$ mutation efficiencies at target loci, the risk of exacerbating off-targeting caused by this method limits their development [97,98]. On the contrary, non-viral vectors offer an excellent ability to take large size genomic drugs and are easily generated. Nevertheless, their clinical applications are limited due to the high toxicity of raw materials, low transfection efficiency, and poor target specificity.

In terms of delivery methods for these gene editing technologies, the current literature indicates that much can be learned from the large body of knowledge obtained from nucleic acid delivery, protein delivery, and technologies developed for specific routes of administration [99]. In addition, the improvement in nanotechnology of pharmaceutics and material science pushes the emergence of novel synthetic vectors with targeting abilities and superior physicochemical characteristics. For example, mesoporous silicon particles [100] and cationic nanoemulsions can be utilized as vectors for plasmid [101]. All of these contribute to the development of in vivo delivery systems for genome editing technologies.

Many investigators have established novel delivery systems. For instance, Zhi Yao He, et al. developed folate-linked lipoplexes to deliver short hairpin RNA (shRNA) to target sites to cure ovarian cancer [102]. This can also be applied to the in vivo delivery of the CRISPR/Cas9 genome editing system. Moreover, long term research highlights the importance of optimizing the Cas9/gRNA system to achieve targeted in vivo delivery and avoid off-target mutations [103]. Three AAV-mediated delivery systems succeeded in delivering CRISPR/Cas9 genome editing system into the muscle of $m d x$ mice in vivo. However, due to the size requirement of AAV $(<4.7 \mathrm{~kb})$, the application of this delivery system is still limited. Considering the situation above, delivery systems which possess large loading capacity for CRISPR/Cas9 plasmids with tissue selectivity would be preferred. Hence, delivery systems for plasmids, having entered into clinical trials including cationic liposomes, cationic polymers, and lipopolymers which are the synthetic complexes of lipids and polymers, are theoretically available for the delivery of genome editing systems (NCT01455389, NCT00595088, NCT01118052, etc., Table 1) [8]. 
Table 1. Summary form of typical in vivo delivery systems and candidates for genome editing nucleases and their expression cassette.

\begin{tabular}{|c|c|c|c|c|c|c|c|c|}
\hline \multirow{2}{*}{\multicolumn{2}{|c|}{ Typical Delivery Systems }} & \multicolumn{2}{|c|}{ Assessment } & \multirow{2}{*}{$\begin{array}{l}\text { Genome Editing } \\
\text { Nuclease }\end{array}$} & \multicolumn{4}{|c|}{ Clinical Trials } \\
\hline & & Advantages & Disadvantages & & Phase & Status & $\begin{array}{l}\text { Clinical Trials. } \\
\text { Gov Identifier }\end{array}$ & Reference \\
\hline \multicolumn{2}{|l|}{ AAVs } & High efficiency & $\begin{array}{l}\text { Low packaging capacity, } \\
\text { cost high }\end{array}$ & $\begin{array}{c}\text { ZFNs, } \\
\text { CRISPR/Cas9 }\end{array}$ & - & - & - & {$[59,73,74,104]$} \\
\hline \multirow{3}{*}{\multicolumn{2}{|c|}{ AdVs }} & \multirow{3}{*}{ Low off-target mutagenesis } & \multirow{3}{*}{ Immunoreactivity, high cost } & \multirow{3}{*}{ ZFNs } & I & Completed & NCT01044654 & \multirow{3}{*}[49,105,106]{} \\
\hline & & & & & II & Completed & NCT01252641 & \\
\hline & & & & & I & Completed & NCT00842634 & \\
\hline \multicolumn{2}{|l|}{ HCAdVs } & High packaging capacity & $\begin{array}{l}\text { Cell-specific targeting is } \\
\text { difficult to achieve }\end{array}$ & TALENs & - & - & - & [32] \\
\hline \multicolumn{2}{|c|}{$\begin{array}{l}\text { CPP, e.g., TAT-TALEN proteins; } \\
\text { CPP-Cas9 proteins }\end{array}$} & Low off-target mutagenesis & Immunoreactivity & $\begin{array}{c}\text { TALENs, } \\
\text { CRISPR/Cas9 }\end{array}$ & - & - & - & {$[63,64,86]$} \\
\hline \multirow{3}{*}{$\begin{array}{l}\text { Candidates for delivering } \\
\text { plasmids of nucleases }\end{array}$} & $\begin{array}{c}\text { DOTAP- } \\
\text { cholesterol }\end{array}$ & $\begin{array}{l}\text { Easy to produce, } \\
\text { large packaging capacity }\end{array}$ & $\begin{array}{l}\text { Large particle size, low } \\
\text { targeting efficiency, toxic }\end{array}$ & - & $\mathrm{I} / \mathrm{II}$ & Active & NCT01455389 & \multirow{3}{*}{ [8] } \\
\hline & PEI & $\begin{array}{c}\text { Easy to produce, } \\
\text { large packaging capacity }\end{array}$ & Low targeting efficiency, toxic & - & II & Active & NCT00595088 & \\
\hline & $\begin{array}{l}\text { PEG-PEI- } \\
\text { Cholesterol }\end{array}$ & $\begin{array}{c}\text { Easy to produce, } \\
\text { large packaging capacity with } \\
\text { small particle size, low toxic }\end{array}$ & Low targeting efficiency & - & II & Active & NCT01118052 & \\
\hline
\end{tabular}

Table 2. Comparison of three programmable nucleases.

\begin{tabular}{|c|c|c|c|c|c|c|c|}
\hline Genome Editing Nucleases & DNA Targeting Specificity Determinant & Endonuclease & Average Mutation Rate & Off-Target Rate & Success Rate & Size & Cytotoxicity \\
\hline ZFNs & Zinc-finger proteins & FokI & $10 \%$ & High & $\sim 24 \%$ & $\sim 1 \mathrm{~kb} \times 2$ & Variable high \\
\hline TALENs & Transcription activator-like effectors & FokI & $20 \%$ & Low & $\sim 99 \%$ & $\sim 3 \mathrm{~kb} \times 2$ & Low \\
\hline CRISPR/Cas9 & crRNA or sgRNA & Cas9 & $20 \%$ & Variable & $\sim 90 \%$ & $4.2 \mathrm{~kb}(\mathrm{SpCas} 9)+0.1 \mathrm{~kb}$ (sgRNA) & Low \\
\hline
\end{tabular}

The success efficiency is defined as the proportion of nucleases inducing mutations at frequencies more than $0.5 \%$ in HEK-293 cell lines. The average mutation efficiency is based on the frequency of non-homologous end joining (NHEJ)-mediated indels obtained at the nuclease target site $[5,94,95,105,107,108]$.

Table 3. Nuclease-mediated genome editing technologies having been used in clinical trials.

\begin{tabular}{|c|c|c|c|c|c|c|c|c|c|c|}
\hline \multirow{2}{*}{$\begin{array}{l}\text { Genome } \\
\text { Editing } \\
\text { Nucleases }\end{array}$} & \multicolumn{10}{|c|}{ Clinical Trials } \\
\hline & Condition & Intervention & Target & Delivery Vector & Cell Transplantation & Company & Phase & Status & $\begin{array}{l}\text { Clinical Trials. } \\
\text { Gov Identifier }\end{array}$ & Reference \\
\hline \multirow{3}{*}{ ZFNs } & \multirow{3}{*}{$\begin{array}{c}\text { HIV } \\
\text { Infection }\end{array}$} & \multirow{3}{*}{ Genetic: SB-728-T } & \multirow{3}{*}{ CCR5 DNA } & \multirow{3}{*}{$\begin{array}{c}\text { AdVs or } \\
\text { direct delivery }\end{array}$} & \multirow{3}{*}{ Autologous $\mathrm{CD} 4^{+} \mathrm{T}$ cells } & \multirow{3}{*}{$\begin{array}{l}\text { Sangamo } \\
\text { Biosciences }\end{array}$} & $\mathrm{I}$ & Completed & NCT01044654 & \multirow{3}{*}[49,106,109]{} \\
\hline & & & & & & & II & Completed & NCT01252641 & \\
\hline & & & & & & & I & Completed & NCT00842634 & \\
\hline TALENs & Leukemia & Malignant blood cells & $\begin{array}{c}\text { Genes in } \\
\text { immune cells }\end{array}$ & N/A & $\begin{array}{l}\text { Chimeric antigen receptor } \\
\text { (CAR) } 19 \mathrm{~T} \text { cells }\end{array}$ & $\begin{array}{l}\text { Great Ormond } \\
\text { Street Hospital }\end{array}$ & N/A & N/A & N/A & [110] \\
\hline
\end{tabular}


Acknowledgments: We thank the other academic staff members in Professor Aiping Lu and Professor Ge Zhang's group at Hong Kong Baptist University. We also thank Hong Kong Baptist University for providing critical comments and technical support. This study was supported by the Hong Kong General Research Fund (HKBU12102914 to Ge Zhang).

Author Contributions: Luyao Wang, Fangfei Li, Lei Dang wrote the manuscript; Chao Liang, Chao Wang, Bing He, Jin Liu, Defang Li, Xiaohao Wu contributed the manuscript for literature research; Xuegong Xu, Aiping Lu and Ge Zhang revised and approved the manuscript.

Conflicts of Interest: The authors declare no conflict of interest.

\section{Glossary}

ZFNs

TALENs

\section{CRISPR/Cas9}

DSB

NHEJ

HDR

Indel一insertion/deletion sgRNA—single-guide RNA PAM

crRNA

tracrRNA

Lentiviral Vectors

(LVs)-Lentiviruses

Adenoviral Vectors

(AdVs)-Adenoviruses

Adeno-associated viral

Vectors (AAVs)-Adenoassociated viruses

\section{Liposomes}

Polymer

\section{Cell-penetrating peptides (CPP)}

Zinc-finger nucleases are fusions of the nonspecific DNA-cleavage domain with zinc finger DNA binding domain. The DNA binding domain can be engineered to direct the ZFN to specific desired DNA sequences, and ZFN induce targeted DSBs.

Transcription activator-like effector nucleases are made by fusing a DNA cleavage domain to a TAL effector DNA binding domain. TAL effectors containing 33 35 amino acid repeat domains can be engineered to recognize base pair. Then TALENs induce targeted DNA DSBs.

Clustered regularly interspaced short palindromic repeat- associated nuclease Cas9 is a prokaryotic immune system against foreign DNA in bacteria or archaea. They consist of a guide RNA (tracrRNA-crRNA)-being used for guiding the Cas9 nuclease to the desired DNA sequence, and Cas9 protein. Double-strand break. A form of DNA damage caused by ZFN, TALEN and CRISPR/Cas9. Both DNA strands will be cleaved.

Non-homologous end joining. A DSB repair pathway which can relink broken ends together. It often leads to small insertions and deletions at the broken site. Homology-directed repair. Another DSB repair pathway by which the donor molecule will be inserted at targeted sites. By HDR, single, multiple transgenes, or single nucleotide substitutions can all be inserted.

A molecular biology term. Insert or delete bases in DNA.

Consists of crRNA and tracrRNA, can direct Cas9-mediated genome editing. Proto-spacer adjacent motifs on crRNA are particularly required and recognized by Cas9 protein.

One CRISPR RNA base pair of the guide RNA in CRISPR/Cas9.

Trans-activating chimeric RNA. Another CRISPR RNA base pair in CRISSPR/Cas9. It can promote crRNA processing.

The replication-defective retroviruses that are applied to introduce the target gene in vivo or in vitro for genome editing.

The replication-defective viruses belong to the family of Adenoviridae. They are always used to carry the designed gene into targeted tissues or cells in vivo or in vitro for genome editing.

The commonly used delivery vector in genome editing technologies for its potential site-specific integration ability and low immunogenic characteristics. They are icosahedral non-enveloped viruses in Dependovirus genus of Parvoviridae family.

Lipid made vesicles which can encapsulate designed DNA or RNA, and carry them into target tissues and cells by fusing to the cell membrane for genome editing in vivo or in vitro.

Co-polymers made vesicles which can encapsulate both genes and proteins, and form particles with different sizes. They can also be utilized for designed genes or proteins delivery in vivo or in vitro to achieve gene editing therapy. Small peptides which can combine with target genes or proteins, and translocate across cell membranes to achieve the delivery and genome editing in vivo or in vitro. 


\section{References}

1. Cox, D.B.; Platt, R.J.; Zhang, F. Therapeutic genome editing: Prospects and challenges. Nat. Med. 2015, 21, 121-131. [CrossRef] [PubMed]

2. Perez-Pinera, P.; Ousterout, D.G.; Gersbach, C.A. Advances in targeted genome editing. Curr. Opin. Chem. Biol. 2012, 16, 268-277. [CrossRef] [PubMed]

3. Kim, Y.G.; Cha, J.; Chandrasegaran, S. Hybrid restriction enzymes: Zinc finger fusions to Fok I cleavage domain. Proc. Natl. Acad. Sci. USA 1996, 93, 1156-1160. [CrossRef] [PubMed]

4. Miller, J.C.; Tan, S.; Qiao, G.; Barlow, K.A.; Wang, J.; Xia, D.F.; Meng, X.; Paschon, D.E.; Leung, E.; Hinkley, S.J.; et al. A TALE nuclease architecture for efficient genome editing. Nat. Biotechnol. 2011, 29, 143-148. [CrossRef] [PubMed]

5. Cho, S.W.; Kim, S.; Kim, J.M.; Kim, J.S. Targeted genome engineering in human cells with the Cas9 RNA-guided endonuclease. Nat. Biotechnol. 2013, 31, 230-232. [CrossRef] [PubMed]

6. Wells, D. Gene Therapy Progress and Prospects: Electroporation and other Physical Methods. Nat. Rev. 2004, 11, 1363-1369. [CrossRef] [PubMed]

7. Thomas, C.E.; Ehrhardt, A.; Kay, M.A. Progress and problems with the use of viral vectors for gene therapy. Nature reviews. Genetics 2003, 4, 346-358. [PubMed]

8. Yin, H.; Kanasty, R.L.; Eltoukhy, A.A.; Vegas, A.J.; Dorkin, J.R.; Anderson, D.G. Non-viral vectors for gene-based therapy. Nat. Rev. Genet. 2014, 15, 541-555. [CrossRef] [PubMed]

9. Van Dommelen, S.M.; Vader, P.; Lakhal, S.; Kooijmans, S.A.; van Solinge, W.W.; Wood, M.J.; Schiffelers, R.M. Microvesicles and exosomes: Opportunities for cell-derived membrane vesicles in drug delivery. J. Control. Release 2012, 161, 635-644. [CrossRef] [PubMed]

10. Vannucci, L.; Lai, M.; Chiuppesi, F.; Ceccherini-Nelli, L.; Pistello, M. Viral vectors: A look back and ahead on gene transfer technology. New Microbiol. 2013, 36, 1-22. [PubMed]

11. Bessis, N.; GarciaCozar, F.J.; Boissier, M.C. Immune responses to gene therapy vectors: Influence on vector function and effector mechanisms. Gene Ther. 2004, 11, S10-S17. [CrossRef] [PubMed]

12. Baum, C.; Kustikova, O.; Modlich, U.; Li, Z.; Fehse, B. Mutagenesis and Oncogenesis by Chromosomal Insertion of Gene Transfer Vectors. Hum. Gene Ther. 2006, 17, 253-263. [CrossRef] [PubMed]

13. Vectors Used in Gene Therapy Clinical Trials. Available online: http://www.wiley.com//legacy/wileychi/ genmed/clinical (accessed on July 2015).

14. Sun, C.Y.; Shen, S.; Xu, C.F.; Li, H.J.; Liu, Y.; Cao, Z.T.; Yang, X.Z.; Xia, J.X.; Wang, J. Tumor Acidity-Sensitive Polymeric Vector for Active Targeted siRNA Delivery. J. Am. Chem. Soc. 2015, 137, 15217-15224. [CrossRef] [PubMed]

15. Hsu, P.D.; Lander, E.S.; Zhang, F. Development and applications of CRISPR-Cas9 for genome engineering. Cell 2014, 157, 1262-1278. [CrossRef] [PubMed]

16. Ul Ain, Q.; Chung, J.Y.; Kim, Y.H. Current and future delivery systems for engineered nucleases: ZFN, TALEN and RGEN. J. Control. Release 2015, 205, 120-127. [CrossRef] [PubMed]

17. Bibikova, M.; Beumer, K.; Trautman, J.K.; Carroll, D. Enhancing Gene Targeting with Designed Zinc Finger Nucleases. Science 2003, 300, 764. [CrossRef] [PubMed]

18. Zhang, Z.; Zhang, S.; Huang, X.; Orwig, K.E.; Sheng, Y. Rapid assembly of customized TALENs into multiple delivery systems. PLoS ONE 2013, 8, e80281. [CrossRef] [PubMed]

19. Urnov, F.D.; Miller, J.C.; Lee, Y.L.; Beausejour, C.M.; Rock, J.M.; Augustus, S.; Jamieson, A.C.; Porteus, M.H.; Gregory, P.D.; Holmes, M.C. Highly efficient endogenous human gene correction using designed zinc-finger nucleases. Nature 2005, 435, 646-651. [CrossRef] [PubMed]

20. Thierry, A.; Dujon, B. Nested chromosomal fragmentation in yeast using the meganuclease I-Sce I: A new method for physical mapping of eukaryotic genomes. Nucleic Acids Res. 1992, 20, 5625-5631. [CrossRef] [PubMed]

21. Chevalier, B.S.; Stoddard, B.L. Homing endonucleases: Structural and functional insight into the catalysts of intron/intein mobility. Nucleic Acids Res. 2001, 29, 3757-3774. [CrossRef] [PubMed]

22. Smith, J.; Grizot, S.; Arnould, S.; Duclert, A.; Epinat, J.C.; Chames, P.; Prieto, J.; Redondo, P.; Blanco, F.J.; Bravo, J.; et al. A combinatorial approach to create artificial homing endonucleases cleaving chosen sequences. Nucleic Acids Res. 2006, 34, e149. [CrossRef] [PubMed] 
23. Galetto, R.; Duchateau, P.; Pâques, F. Targeted approaches for gene therapy and the emergence of engineered meganucleases. Expert Opin. Biol. Ther. 2015, 9, 1289-1306. [CrossRef] [PubMed]

24. Chames, P.; Epinat, J.C.; Guillier, S.; Patin, A.; Lacroix, E.; Pâques, F. In vivo selection of engineered homing endonucleases using double-strand break induced homologous recombination. Nucleic Acids Res. 2005, 33, e178. [CrossRef] [PubMed]

25. Chapdelaine, P.; Pichavant, C.; Rousseau, J.; Pâques, F.; Tremblay, J.P. Meganucleases can restore the reading frame of a mutated dystrophin. Gene Ther. 2010, 17, 846-858. [CrossRef] [PubMed]

26. Gouble, A.; Smith, J.; Bruneau, S.; Perez, C.; Guyot, V.; Cabaniols, J.-P.; Leduc, S.; Fiette, L.; Av'e, P.; Micheau, B.; et al. Efficient in toto targeted recombination inmouse liver by meganuclease-induced double-strand break. J. Gene Med. 2006, 8, 616-622. [CrossRef] [PubMed]

27. Izmiryan, A.; Basmaciogullari, S.; Henry, A.; Paques, F.; Danos, O. Efficient gene targeting mediated by a lentiviral vector-associated meganuclease. Nucleic Acids Res. 2011, 39, 7610-7619. [CrossRef] [PubMed]

28. Urnov, F.D.; Rebar, E.J.; Holmes, M.C.; Zhang, H.S.; Gregory, P.D. Genome editing with engineered zinc finger nucleases. Nat. Rev. 2010, 11, 636-643. [CrossRef] [PubMed]

29. Kim, H.; Kim, J.-S. A guide to genome engineering with programmable nucleases. Nat. Rev. Genet. 2014, 15, 321-334. [CrossRef] [PubMed]

30. Blaese, R.M.; Culver, K.W.; Miller, A.D.; Carter, C.S.; Fleisher, T.; Clerici, M.; Shearer, G.; Chang, L.; Chiang, Y.; Tolstoshev, P.; et al. T Lymphocyte-Directed Gene Therapy for ADASCID: Initial Trial Results after 4 Years. Science 1995, 270, 475-480. [CrossRef] [PubMed]

31. Giacca, M.; Zacchigna, S. Virus-mediated gene delivery for human gene therapy. J. Control. Release 2012, 161, 377-388. [CrossRef] [PubMed]

32. Bergmann, T.; Schulz, E.; Ehrhardt, A. Progress and Problems with Viral Vectors for Delivery of TALENs. J. Mol. Genet. Med. 2014, 8, 1-7. [CrossRef]

33. Campos, S.K.; Barry, M.A. Current Advances and Future Challenges in Adenoviral Vector Biology and Targeting. Curr. Gene Ther. 2007, 7, 189-204. [CrossRef] [PubMed]

34. Cannon, P.; June, C. Chemokine receptor 5 knockout strategies. Curr. Opin. HIV AIDS 2011, 6, 74-79. [CrossRef] [PubMed]

35. Huang, S.; Kamihira, M. Development of hybrid viral vectors for gene therapy. Biotechnol. Adv. 2013, 31, 208-223. [CrossRef] [PubMed]

36. Thomas, C.E.; Ehrhardt, A.; Kay, M.A. Progress and Problems with the Use of Viral Vectors for Gene Therapy. Nat. Rev. 2003, 4, 346-359. [CrossRef] [PubMed]

37. Matrai, J.; Chuah, M.K.; VandenDriessche, T. Recent advances in lentiviral vector development and applications. Mol. Ther. 2010, 18, 477-490. [CrossRef] [PubMed]

38. Lombardo, A.; Genovese, P.; Beausejour, C.M.; Colleoni, S.; Lee, Y.L.; Kim, K.A.; Ando, D.; Urnov, F.D.; Galli, C.; Gregory, P.D.; et al. Gene editing in human stem cells using zinc finger nucleases and integrase-defective lentiviral vector delivery. Nat. Biotechnol. 2007, 25, 1298-1306. [CrossRef] [PubMed]

39. Apolonia, L.; Waddington, S.N.; Fernandes, C.; Ward, N.J.; Bouma, G.; Blundell, M.P.; Thrasher, A.J.; Collins, M.K.; Philpott, N.J. Stable gene transfer to muscle using non-integrating lentiviral vectors. Mol. Ther. 2007, 15, 1947-1954. [CrossRef] [PubMed]

40. Gellhaus, K.; Cornu, T.I.; Heilbronn, R.; Cathomen, T. Fate of Recombinant Adeno-Associated Viral Vector Genomes during DNA Double-Strand Break-Induced Gene Targeting in Human Cells. Hum. Gene Ther. 2010, 21, 543-553. [CrossRef] [PubMed]

41. Ellis, B.L.; Hirsch, M.L.; Porter, S.N.; Samulski, R.J.; Porteus, M.H. Zinc-finger nuclease-mediated gene correction using single AAV vector transduction and enhancement by Food and Drug Administrationapproved drugs. Nat. Ther. 2013, 20, 35-42. [CrossRef] [PubMed]

42. Anguela, X.M.; Sharma, R.; Doyon, Y.; Miller, J.C.; Li, H.; Haurigot, V.; Rohde, M.E.; Wong, S.Y.; Davidson, R.J.; Zhou, S.; et al. Robust ZFN-mediated genome editing in adult hemophilic mice. Blood J. 2013, 122, 3283-3287. [CrossRef] [PubMed]

43. Händel, E.M.; Gellhaus, K.; Khan, K.; Bednarski, C.; Cornu, T.I.; Müller-Lerch, F.; Kotin, R.M.; Heilbronn, R.; Cathomen, T. Versatile and Efficient Genome Editing in Human Cells by Combining Zinc-Finger Nucleases with Adeno-Associated Viral Vectors. Hum. Gene Ther. 2012, 23, 321-329. [CrossRef] [PubMed] 
44. Rahman, S.H.; Bobis-Wozowicz, S.; Chatterjee, D.; Gellhaus, K.; Pars, K.; Heilbronn, R.; Jacobs, R.; Cathomen, T. The Nontoxic Cell Cycle Modulator Indirubin Augments Transduction of Adeno-Associated Viral Vectors and Zinc-Finger Nuclease-Mediated Gene Targeting. Hum. Gene Ther. 2013, 24, 67-77. [CrossRef] [PubMed]

45. Michael, J.; Metzger, A.M.-S.; Stoddard, B.L.; Miller, A.D. Single-strand nicks induce homologous recombination with less toxicity than double-strand breaks using an AAV vector template. Nucleic Acids Res. 2011, 39, 926-935.

46. Hojun, L.; Harigot, V.; Doyon, Y.; Li, J.; Bhagwat, A.; Wong, S.; Anguela, X.; Sharma, R.; Ivanciu, L.; Murphy, S.M.; et al. LBA-5 Phenotypic Correction of a Mouse Model of Hemophilia B by in vivo Genetic Correction of F9 Gene. In Proceedings of the American Society of Hematology Annual Meeting, San Diego, CA, USA, 10-13 December 2010.

47. Philip, L.; Felgener, T.R.G.; Holm, M.; Roman, R.; Chen, H.W.; Wenz, M.; Northrop, J.P.; Ringold, G.M.; Dsnielsen, M. Lipofection: A highly efficient, lipid-mediated DNA-transfection procedure. Proc. Natl. Acad. Sci. USA 1987, 84, 7413-7417.

48. Almofti, M.R.; Harashima, H.; Shinohara, Y.; Almofti, A.; Baba, Y.; Kiwada, H. Cationic liposome-mediated gene delivery: Biophysical study and mechanism of internalization. Arch. Biochem. Biophys. 2003, 410, 246-253. [CrossRef]

49. Perez, E.E.; Wang, J.B.; Miller, J.C.; Jouvenot, Y.; Kim, K.A.; Liu, O.; Wang, N.; Lee, G.; Bartsevich, V.V.; Lee, Y.; et al. Establishment of HIV-1 resistance in $\mathrm{CD}^{+} \mathrm{T}$ cells by genome editing using zinc-finger nucleases. Nat. Biothechnol. 2008, 26, 808-817. [CrossRef] [PubMed]

50. Wong, A.W.; Baginski, T.K.; Reilly, D.E. Reilly, Enhancement of DNA Uptake in FUT8-Deleted CHO Cells for Transient Production of Afucosylated Antibodies. Biotechnol. Bioeng. 2010, 106, 751-763. [CrossRef] [PubMed]

51. Gaj, T.; Guo, J.; Kato, Y.; Sirk, S.J.; Barbas, C.F., 3rd. Targeted gene knockout by direct delivery of zinc-finger nuclease proteins. Nat. Methods 2012, 9, 805-812. [CrossRef] [PubMed]

52. Kim, S.; Kim, D.; Cho, S.W.; Kim, J.; Kim, J. Highly efficient RNA-guided genome editing in human cells via delivery of purified Cas9 ribonucleoproteins. Genome Res. 2014, 24, 1012-1019. [CrossRef] [PubMed]

53. Ramakrishna, S.; Kim, Y.H.; Kim, H. Stability of Zinc Finger Nuclease Protein Is Enhanced by the Proteasome Inhibitor MG132. PLoS ONE 2013, 8, e54282. [CrossRef] [PubMed]

54. Jo, Y.I.; Kim, H.; Ramakrishna, S. Recent developments and clinical studies utilizing engineered zinc finger nuclease technology. Cell. Mol. Life Sci. 2015, 72, 3819-3830. [CrossRef] [PubMed]

55. Li, H.; Haurigot, V.; Doyon, Y.; Li, T.; Wong, S.Y.; Bhagwat, A.S.; Malani, N.; Anguela, X.M.; Sharma, R.; Ivanciu, L.; et al. In vivo genome editing restores haemostasis in a mouse model of haemophilia. Nature 2011, 475, 217-224. [CrossRef] [PubMed]

56. Mussolino, C.; Morbitzer, R.; Lütge, F.; Dannemann, N.; Lahaye, T.; Cathomen, T. A novel TALE nuclease scaffold enables high genome editing activity in combination with low toxicity. Nucleic Acids Res. 2011, 39, 9283-9293. [CrossRef] [PubMed]

57. Zhu, H.; Lau, C.H.; Goh, S.L.; Liang, Q.; Chen, C.; Du, S.; Phang, R.Z.; Tay, F.C.; Tan, W.K.; Li, Z.; et al. Baculoviral transduction facilitates TALEN-mediated targeted transgene integration and Cre/LoxP cassette exchange in human-induced pluripotent stem cells. Nucleic Acids Res. 2013, 41, e180. [CrossRef] [PubMed]

58. Cai, M.; Yang, Y. Targeted Genome Editing Tools for Disease Modeling and Gene Therapy. Curr. Gene Ther. 2014, 14, 2-9. [CrossRef] [PubMed]

59. Nelson, C.E.; Hakim, C.H.; Ousterout, D.G.; Thakore, P.I.; Moreb, E.A.; Rivera, R.M.C.; Zhang, F.; Madhavan, S.; Duan, D.; Ousterout, D.G.; et al. In vivo genome editing improves muscle function in a mouse model of Duchenne muscular dystrophy. Science 2016, 351, 403-407. [CrossRef] [PubMed]

60. Holkers, M.; de Vries, A.A.F.; Gonçalves, M.A.F.V. Nonspaced inverted DNA repeats are preferential targets for homology-directed gene repair in mammalian cells. Nucleic Acids Res. 2012, 40, 1984-1999. [CrossRef] [PubMed]

61. Holkers, M.; Maggio, I.; Liu, J.; Janssen, J.M.; Miselli, F.; Mussolino, C.; Recchia, A.; Cathomen, T.; Gonçalves, M.A. Differential integrity of TALE nuclease genes following adenoviral and lentiviral vector gene transfer into human cells. Nucleic Acids Res. 2012, 41, e63. [CrossRef] [PubMed] 
62. Hu, Z.; Ding, W.; Zhu, D.; Yu, L.; Jiang, X.; Wang, X.; Zhang, C.; Wang, L.; Ji, T.; Liu, D.; et al. TALEN-mediated targeting of HPV oncogenes ameliorates HPV-related cervical malignancy. J. Clin. Investig. 2015, 125, 425-537. [CrossRef] [PubMed]

63. Ru, R.; Yao, Y.; Yu, S.; Yin, B.; Xu, W.; Zhao, S.; Qin, L.; Chen, X. Targeted genome engineering in human induced pluripotent stem cells by penetrating TALENs. Cell Regen. 2013, 2, 5. [CrossRef] [PubMed]

64. Liu, J.; Gaj, T.; Patterson, J.T.; Sirk, S.J.; Barbas, C.F. Cell-penetrating peptide-mediated delivery of TALEN proteins via bioconjugation for genome engineering. PLOS ONE 2014, 9, e85755. [CrossRef] [PubMed]

65. Wiedenheft, B.; Sternberg, S.H.; Doudna, J.A. RNA-guided genetic silencing systems in bacteria and archaea. Nat. Rev. 2012, 482, 331-339. [CrossRef] [PubMed]

66. Peter, C.; Fineran, E.C. Memory of viral infections by CRISPR-Cas adaptive immune systems: Acquisition of new information. Virology 2012, 434, 202-209.

67. Barrangou, R.; Fremaux, C.; Deveau, H.; Richards, M.; Boyaval, P.; Moineau, S.; Romero, D.A.; Horvath, P. CRISPR Provides Acquired Resistance against Viruses in Prokaryotes. Sci. Rep. 2007, 315, 23-28. [CrossRef] [PubMed]

68. Horvath, P.; Barrangou, R. CRISPR/Cas, the Immune System of Bacteria and Archaea. Science 2010, 327, 167-172. [CrossRef] [PubMed]

69. Makarova, K.S.; Aravind, L.; Grishin, N.V.; Rogozin, I.B.; Koonin, E.V. A DNA repair system specific for thermophilic Archaea and bacteria predicted by genomic context analysis. Nucleic Acids Res. 2002, 30, 482-496. [CrossRef] [PubMed]

70. Heidenreich, M.; Zhang, F. Applications of CRISPR-Cas system in neuroscience. Nat. Rev. Neurosci. 2015, 17, 36-44. [CrossRef] [PubMed]

71. Ran, F.A.; Cong, L.; Yan, W.X.; Scott, D.A.; Gootenberg, J.S.; Kriz, A.J.; Zetsche, B.; Shalem, O.; Wu, X.; Makarova, K.S.; et al. In vivo genome editing using Staphylococcus aureus Cas9. Nature 2015, 520, 186-191. [CrossRef] [PubMed]

72. Swiech, L.; Heidenreich, M.; Banerjee, A.; Habib, N.; Li, Y.; Trombetta, J.; Sur, M.; Zhang, F. In vivo interrogation of gene function in the mammalian brain using CRISPR-Cas9. Nat. Biotechnol. 2015, 33, 102-106. [CrossRef] [PubMed]

73. Tabebordbar, M.; Zhu, K.; Cheng, J.K.; Chew, W.L.; Widrick, J.J.; Yan, W.X.; Maesner, C.; Wu, E.Y.; Xiao, R.; Ran, F.A.; et al. In vivo gene editing in dystrophic mouse muscle and muscle stem cells. Science 2016, 351, 407-411. [CrossRef] [PubMed]

74. Long, C.; Amoasii, L.; Mireault, A.A.; McAnally, J.R.; Li, H.; Sanchez-Ortiz, E.; Bhattacharyya, S.; Shelton, J.M.; Bassel-Duby, R.; Olson, E.N. Postnatal genome editing partially restores dystrophin expression in a mouse model of muscular dystrophy. Science 2016, 351, 400-403. [CrossRef] [PubMed]

75. Lai, Y.; Yue, Y.; Liu, M.; Ghosh, A.; Engelhardt, J.F.; Chamberlain, J.S.; Duan, D. Efficient in vivo gene expression by trans-splicing adeno-associated viral vectors. Nat. Biotechnol. 2005, 23, 1435-1439. [CrossRef] [PubMed]

76. Murlidharan, G.; Samulski, R.J.; Asokan, A. Biology of adeno-associated viral vectors in the central nervous system. Front. Mol. Neurosci. 2014, 7, 76-85. [CrossRef] [PubMed]

77. Platt, R.J.; Chen, S.; Zhou, Y.; Yim, M.J.; Swiech, L.; Kempton, H.R.; Dahlman, J.E.; Parnas, O.; Eisenhaure, T.M.; Jovanovic, M.; et al. CRISPR-Cas9 Knockin Mice for Genome Editing and Cancer Modeling. Cell 2014, 159, 440-455. [CrossRef] [PubMed]

78. Senis, E.; Fatouros, C.; Grosse, S.; Wiedtke, E.; Niopek, D.; Mueller, A.K.; Borner, K.; Grimm, D. CRISPR/Cas9-mediated genome engineering: An adeno-associated viral (AAV) vector toolbox. Biotechnol. J. 2014, 9, 1402-1412. [CrossRef] [PubMed]

79. Kennedy, E.M.; Kornepati, A.V.; Mefferd, A.L.; Marshall, J.B.; Tsai, K.; Bogerd, H.P.; Cullen, B.R. Optimization of a multiplex CRISPR/Cas system for use as an antiviral therapeutic. Methods 2015, 91, 82-86. [CrossRef] [PubMed]

80. Cheng, R.; Peng, J.; Yan, Y.; Cao, P.; Wang, J.; Qiu, C.; Tang, L.; Liu, D.; Tang, L.; Jin, J.; et al. Efficient gene editing in adult mouse livers via adenoviral delivery of CRISPR/Cas9. FEBS Lett. 2014, 588, 3954-3958. [CrossRef] [PubMed]

81. Zuris, J.A.; Thompson, D.B.; Shu, Y.; Guilinger, J.P.; Bessen, J.L.; Hu, J.H.; Maeder, M.L.; Joung, J.K.; Chen, Z.Y.; Liu, D.R. Cationic lipid-mediated delivery of proteins enables efficient protein-based genome editing in vitro and in vivo. Nat. Biotechnol. 2015, 33, 73-80. [CrossRef] [PubMed] 
82. Wightman, L.; Kircheis, R.; Rössler, V.; Carotta, S.; Ruzicka, R.; Kursa, M.; Wagner, E. Different behavior of branched and linear polyethylenimine for gene delivery in vitro and in vivo. J. Gene Med. 2011, 3, 362-372. [CrossRef] [PubMed]

83. Zuckermann, M.; Hovestadt, V.; Knobbe-Thomsen, C.B.; Zapatka, M.; Northcott, P.A.; Schramm, K.; Belic, J.; Jones, D.T.; Tschida, B.; Moriarity, B.; et al. Somatic CRISPR/Cas9-mediated tumour suppressor disruption enables versatile brain tumour modelling. Nat. Commun. 2015, 6, 7391-7400. [CrossRef] [PubMed]

84. Li, L.; He, Z.Y.; Wei, X.W.; Gao, G.P.; Wei, Y.Q. Challenges in CRISPR/CAS9 Delivery: Potential Roles of Nonviral Vectors. Hum. Gene Ther. 2015, 26, 452-462. [CrossRef] [PubMed]

85. Alvarez, R.D.; Sill, M.W.; Davidson, S.A.; Muller, C.Y.; Bender, D.P.; DeBernardo, R.L.; Behbakht, K.; Huh, W.K. A phase II trial of intraperitoneal EGEN-001, an IL-12 plasmid formulated with PEG-PEIcholesterol lipopolymer in the treatment of persistent of recurrent epithelial ovarian, fallopian tube or primary peritoneal cancer: A gynecologic oncology group study. Gynecol. Oncol. 2014, 3, 571-577. [CrossRef] [PubMed]

86. Ramakrishna, S.; Kwaku Dad, A.B.; Beloor, J.; Gopalappa, R.; Lee, S.K.; Kim, H. Gene disruption by cell-penetrating peptide-mediated delivery of Cas9 protein and guide RNA. Genome Res. 2014, 24, 1020-1027. [CrossRef] [PubMed]

87. Yin, H.; Song, C.Q.; Dorkin, J.R.; Zhu, L.J.; Li, Y.; Wu, Q.; Park, A.; Yang, J.; Suresh, S.; Bizhanova, A.; et al . Therapeutic genome editing by combined viral and non-viral delivery of CRISPR system components in vivo. Nat. Biotechnol. 2016, 34, 328-333. [CrossRef] [PubMed]

88. Findlay, G.M.; Boyle, E.A.; Hause, R.J.; Klein, J.C.; Shendure, J. Saturation editing of genomic regions by multiplex homology-directed repair. Nature 2014, 513, 120-123. [CrossRef] [PubMed]

89. Yin, H.; Xue, W.; Chen, S.; Bogorad, R.L.; Benedetti, E.; Grompe, M.; Koteliansky, V.; Sharp, P.A.; Jacks, T.; Anderson, D.G. Genome editing with Cas9 in adult mice corrects a disease mutation and phenotype. Nat. Biotechnol. 2014, 32, 551-553. [CrossRef] [PubMed]

90. Xue, W.; Chen, S.; Yin, H.; Tammela, T.; Papagiannakopoulos, T.; Joshi, N.S.; Cai, W.; Yang, G.; Bronson, R.; Crowley, D.G. CRISPR-mediated directmutation of cancer genes in themouse liver. Nature 2014, 514, 380-396. [CrossRef] [PubMed]

91. Jo, Y.I.; Suresh, B.; Kim, H.; Ramakrishna, S. CRISPR/Cas9 system as an innovative genetic engineering tool: Enhancements in sequence specificity and delivery methods. Biochim. Biophys. Acta 2015, 1856, 234-243. [CrossRef] [PubMed]

92. Rieder, F.; Steininger, C. Cytomegalovirus vaccine: Phase II clinical trial results. Clin. Microbiol. Infect. 2013, 20, 95-103. [CrossRef] [PubMed]

93. Kim, J.S.; Lee, H.J.; Carroll, D. Genome editing with modularly assembled zinc-finger nucleases. Nat. Methods 2010, 7, 91. [CrossRef] [PubMed]

94. Kim, Y.; Kweon, J.; Kim, A.; Chon, J.K.; Yoo, J.Y.; Kim, H.J.; Kim, S.; Lee, C.; Jeong, E.; Chung, E.; et al. A library of TAL effector nucleases spanning the human genome. Nat. Biotechnol. 2013, 31, 251-258. [CrossRef] [PubMed]

95. Cornu, T.I.; Thibodeau-Beganny, S.; Guhl, E.; Alwin, S.; Eichtinger, M.; Joung, J.K.; Cathomen, T. DNA-binding Specificity Is a Major Determinant of the Activity and Toxicity of Zinc-finger Nucleases. Mol. Ther. 2008, 16, 352-358. [CrossRef] [PubMed]

96. Maggio, I.; Holkers, M.; Liu, J.; Janssen, J.M.; Chen, X.; Gonçalves, M.A.F.V. Adenoviral vector delivery of RNA-guided CRISPR/Cas9 nuclease complexes induces targeted mutagenesis in a diverse array of human cells. Sci. Rep. 2014, 4, 1-11. [CrossRef] [PubMed]

97. Shalem, O.; Sanjana, N.E.; Hartenian, E.; Shi, X.; Scott, D.A.; Mikkelsen, T.S.; Heckl, D.; Ebert, B.L.; Root, D.E.; Doench, J.G.; et al. Genome-Scale CRISPR-Cas9 Knockout Screening in Human Cells. Science 2014, 343, 84-89. [CrossRef] [PubMed]

98. Wang, T.; Wei, J.J.; Sabatini, D.M.; Lander, E.S. Genetic screens in human cells using the CRISPR-Cas9 system. Science 2014, 343, 80-86. [CrossRef] [PubMed]

99. McNeer, N.A.; Anandalingam, K.; Fields, R.J.; Caputo, C.; Kopic, S.; Gupta, A.; Quijano, E.; Polikoff, L.; Kong, Y.; Bahal, R.; et al. Nanoparticles that deliver triplex-forming peptide nucleic acid molecules correct F508del CFTR in airway epithelium. Nat. Commun. 2015, 6, 6952. [CrossRef] [PubMed] 
100. Tasciotti, E.; Liu, X.; Bhavane, R.; Plant, K.; Leonard, A.D.; Price, B.K.; Cheng, M.M.; Decuzzi, P.; Tour, J.M.; Robertson, F.; et al. Mesoporous silicon particles as a multistage delivery system for imaging and therapeutic applications. Nat. Nanotechnol. 2008, 3, 151-157. [CrossRef] [PubMed]

101. Liu, C.H.; Yu, S.Y. Cationic nanoemulsions as non-viral vectors for plasmid DNA delivery. Colloids Surf. B Biointerfaces 2010, 79, 509-515. [CrossRef] [PubMed]

102. He, Z.Y.; Wei, X.W.; Luo, M.; Luo, S.T.; Yang, Y.; Yu, Y.Y.; Chen, Y.; Ma, C.C.; Liang, X.; Guo, F.C. Folate-linked lipoplexes for short hairpin RNA targeting claudin-3 delivery in ovarian cancer xenografts. J. Control. Release 2013, 172, 679-689. [CrossRef] [PubMed]

103. Cho, S.W.; Kim, S.; Kim, Y.; Kweon, J.; Kim, H.S.; Bae, S.; Kim, J. Analysis of off-target effects of CRISPR/Cas-derived RNA-guided endonucleases and nickases. Genome Res. 2014, 24, 132-141. [CrossRef] [PubMed]

104. Francisco Martín, K.B.; Cobo, M.; Muñoz, P.; Anderson, P.; Toscano, M.G. New Vectors for Stable and Safe Gene Modification. Gene Therapy_Developments and Future Perspectives; InTech: Rijeka, Croatia, 2011; pp. 1-29. ISBN: 978-953-307-617-1.

105. Klein, T.; Loschberger, A.; Proppert, S.; Wolter, S.; van de Linde, S.; Sauer, M. Live-cell dSTORM with SNAP-tag fusion proteins. Nat. Methods 2011, 8, 7-9. [CrossRef] [PubMed]

106. Tebas, P.; Stein, D.; Tang, W.W.; Frank, I.; Wang, S.Q.; Lee, G.; Spratt, S.K.; Surosky, R.T.; Giedlin, M.A.; Nichol, G.; et al. Gene editing of CCR5 in autologous CD4 T cells of persons infected with HIV. N. Engl. J. Med. 2014, 370, 901-910. [CrossRef] [PubMed]

107. Kim, H.J.; Lee, H.J.; Kim, H.; Cho, S.W.; Kim, J.S. Targeted genome editing in human cells with zinc finger nucleases constructed via modular assembly. Genome Res. 2009, 19, 1279-1288. [CrossRef] [PubMed]

108. Kim, Y.; Kweon, J.; Kim, J.S. TALENs and ZFNs are associated with different mutation signatures. Nat. Methods 2013, 10, 185. [CrossRef] [PubMed]

109. Burnett, J.C.; Zaia, J.A.; Rossi, J.J. Creating genetic resistance to HIV. Curr. Opin. Immunol. 2012, $24,625-632$. [CrossRef] [PubMed]

110. Qasim, W.; Amrolia, P.J.; Samarasinghe, S.; Ghorashian, S.; Zhan, H.; Stafford, S.; Butler, K.; Ahsan, G.; Gilmour, K.; Adams, S.; et al. First Clinical Application of Talen Engineered Universal CAR19 T Cells in B-ALL. Blood 2015, 126, 2046.

(C) 2016 by the authors; licensee MDPI, Basel, Switzerland. This article is an open access article distributed under the terms and conditions of the Creative Commons Attribution (CC-BY) license (http://creativecommons.org/licenses/by/4.0/). 